\title{
An economic analysis of a timeshare ownership
}

Received (in revised form): 11 October 2007

\section{Atupele Powanga}

is student in the Communications department at the University of Colorado at Boulder.

\section{Luka Powanga}

is a professor of International Business and Economics and MBA Degree Chair at Regis University. He has authored papers, a case and a textbook.

\begin{abstract}
Timeshare vacation ownership, a purchase of the right to occupy accommodation or a facility for a defined period of time during a year over a specified number of years or perpetually, has over the past 30 years experienced a significant and sustained growth to become one of the most sought after products in the hospitality industry. The timeshare industry grew from \$50m in 1975 to \$10bn in 2006 fueling a significant increase in the industry capacity. This paper ascertains why timeshares have gained so much significance to hotel developers and to explore whether consumers should invest in timeshare vacation ownership. Two divergent factors combined to drive the popularity of timeshares ownership among hotel owners. First, the multiple sources of income namely contract sales, interest payments and maintenance and club membership fees. Secondly, timeshares are immune to economic performance. Timeshares are not suitable as investment properties because prices are inflated to cater for the expensive marketing programmes, which account for more than 43 per cent of the contract price. However, industry surveys suggest that the owners are generally satisfied. Consumers should not enter into timeshare vacation contracts for investment purposes but for buying a vacation in advance. Even then, it is better to purchase outright instead of financing the purchase.
\end{abstract}

\section{Keywords:}

timeshares, intervals, fractional ownership, vacation ownership, private residence clubs, destination clubs, exchange programmes

Journal of Retail and Leisure Property (2008) 7, 69-83. doi:10.1057/palgrave.rlp.5100082

Luka Powanga

School of Management

Regis University

3333 Regis Blvd

Denver, CO 80221, USA

Tel: +13034584023

E-mail: Lpowanga@regis.edu

\section{INTRODUCTION}

Timeshare vacation ownership, a purchase of the right to occupy accommodation or a facility for a defined period of time during a year over a specified number of years or perpetually, has experienced a 
significant and sustained growth over the past 30 years to become one of the most sought-after products in the hospitality industry. The timeshare industry grew from $\$ 50 \mathrm{~m}$ in 1975 to $\$ 10 \mathrm{bn}$ in 2006 , fuelling a significant increase in the industry capacity. Between August 2005 and August 2006, the number of rooms in the pipeline increased by 68 per cent from 359,000 to 602,000 (Freitag, 2007). Even more important, the 2005 US sales at $\$ 8.548 \mathrm{bn}$ were less than 3 per cent of the potential timeshare vacation owners, leaving more than ample room for growth.

Despite this unparalleled growth, very limited scholastic literature exists about the industry and the little that is available is mostly obsolete because of the rapid growth in the scope and diversity of offerings. This paper seeks to help fill the literature void by ascertaining why timeshares have gained so much significance to hotel developers and to explore whether consumers should invest in timeshare vacation ownership. The paper begins with a review of the literature to assess the state of the art of the industry including an explanation of the purpose and contribution of the paper to the current body of literature to establish its importance. Next, a brief overview of the services and the general structure of a timeshare project are discussed to provide the foundation for the ensuing methodology and analysis. The results are followed by conclusions.

\section{REVIEW OF LITERATURE, PURPOSE AND IMPORTANCE OF THE STUDY}

Considerable literature on timeshare ownership exists especially in real estate appraisal and legal reports, professional and trade journals such as the Vacation Ownership World (Scott, 2007) the Journal of Retail and Leisure Property, the Appraisal Journal and Cornell Hotel and Restaurant Administration Quarterly, consulting companies (Ragatz Associates ${ }^{1}$ and $\mathrm{TMC}^{2}$ ), organisations representing the resort industry $\left(\mathrm{ARDA}^{3}\right)$ and timeshare industry providers $\left(\mathrm{RCI}^{4}\right)$. Scholastic literature, however, is very limited. The current scholastic literature includes Woods (2001), who discussed the major challenges facing the timeshare industry and generated a laundry list that includes ethics, capitalisation costs, regulations, marketing costs, sales practices and timeshare resale issues. Sparks et al. (2007) surveyed timeshare owners to ascertain where value is derived from. They concluded that as owners became aware of other options for using their timeshare units such as renting out, exchanging for other resort locations or converting to points that could be used to purchase services like stays at other resorts or plane tickets, the timeshare value increased. Sing and Horwitz (2006) explored the role of the elected Board of Directors over the Home Owners Association in fostering successful timeshare resort operations. ARDA (2002), Crotts and Ragatz (2002), Ragatz Associates ${ }^{1}$ and Interval International (2003) analysed the motivations, satisfaction patterns and profiles of the timeshare owners. A typical buyer was over 50 years old, motivated by the convenience and flexibility of the timeshare arrangement, generally pleased with the services offered and grossing over $\$ 75,000$ in annual income. Wade (1986) and Ziobrowski and Ziobrowski (1997) provided models for determining the timeshare value using capital budgeting techniques. 
There is a great need, however, for scholastic literature focused on applying the models to timeshare ownership decisions. For many buyers, the timeshare industry is shrouded in a mystery because of the lack of such literature. This paper seeks to contribute to closing this gap. Unlike the studies reviewed above, the purpose of this paper is not to provide a model for evaluating timeshares as property investments. The primary objective is (a) a comparative economic analysis between an investment in hotel lodging (business as usual) and a similar investment in a timeshare resort to determine why timeshares have become popular among developers, and (b) to compare the cost of investing in future vacations paying hotel rates at the time the vacations occur, and purchasing a timeshare vacation using two alternatives: (i) equity and (ii) mortgage arrangement to rank the alternatives by cost, with the best alternative being the lowest cost. The secondary objective is to ascertain whether consumers should purchase timeshare vacations and if so, the best choices available to them. The above objectives underscore the importance of this study. Before describing the methodology, however, a digression to discussing the timeshare products and the stages in the timeshare project is in order to understand the backdrop against which the analysis is framed.

\section{TIMESHARE PRODUCTS}

\section{Definition}

Consider a frequent vacationer who wishes to buy a vacation home to be occupied for a few weeks out of the year over several years. To avoid the responsibility of keeping the home in good condition all year-round over that period for a property that will seldom be used, the vacationer may decide to share the ownership of the vacation home with other vacationers who would occupy the home at designated times of the year, and split both the cost of the home and the maintenance costs, allowing the vacationer to pay only a fraction of the cost of the whole property as well as the maintenance fees.

This is the concept underlying timeshares, also known as intervals, fractional or vacation ownership. Luxury condominiums and hotel resorts, usually three stars or better, divide their resort units into weeks of stay and each week is sold to different individuals at different price points depending on the size of the unit. For example, if a hotel resort has 100 units, each unit will be rented out for a week, making available 5,200 weeks ${ }^{5}$ for sale. A studio with a kitchenette may be sold for $\$ 18,000$, while a three-bedroom unit with a full kitchen may fetch $\$ 35,000$. The vacation owner gets the right to occupy the purchased unit during the allocated time slot every year. For example, if week 1 (first week of January) is purchased, the owner occupies the unit during that week every year over the life of the contract.

The unit floor plans vary from a studio with a kitchen to five bedrooms with a full kitchen equipped with a wide range of luxury amenities such as a swimming pool, sauna, spa, gymnasium and a golf course. The smaller unit can be combined with the larger unit to form a two-bedroom unit. 
The hotel resort developer, homeownership association or a management company maintains the facility, with the associated costs levied to the vacation owners based on the degree of ownership. The owner of a threebedroom unit will pay more in maintenance costs than a studio owner.

This initial arrangement was too restrictive to appeal to a wider audience. Over time, timeshare ownerships morphed into a myriad of products, presented below, suitable for consumers with varying incomes and needs.

\section{Types of timeshare ownership}

The ownership types can be decomposed into a deeded property ownership and the right of use.

Deeded property ownership also known as fee simple: This is a title-based property ownership similar to a normal home ownership. Once the vacation owner purchases a week in a particular unit, the buyer holds a title to that week, recorded by the land court or appropriate authorities giving the purchaser the right in perpetuity to sell, assign, exchange or rent the unit just like any other piece of property.

The right of use ownership: This is similar to deeded property ownership with the exception that the right of use or lease has an expiration period that may have a renewal option. The purchasers of the units acquire the right to utilise the unit for a specified timeframe say 10-25 years or even forever without placing them in an equity position. The right of use contract has two main options.

One is the point credit or point. The units are divided into weeks just like in the case of the deeded units or in equivalent points or credits called 'intervals', with the required points varying according to the size of the unit (studio to five bedrooms) and length of stay (from a day to multiple vacations in different locations each year). Points may be exchanged for air flights and hotel accommodation, or other activities.

The other option requires the buyer to lease, license or acquire membership in a resort chain. For a specific period over a defined number of years, the owner has the right to occupy a unit in any of the chain's hotel and/or condominium properties without any ownership interest in the real estate; the developer owns the property. The vacation owners, however, still pay the annual maintenance fees.

\section{Product variations}

There are a variety of products designed to appeal to customers of varying incomes and requirements.

Fixed or floating time: In a fixed-time option, the vacation owner occupies the unit for a designated week every year. For instance, purchasing the last week of December in a three-bedroom unit say number 12, entitles the owner to use this unit every last week in December in unit number 12. In contrast, the floating-time option allows the unit owner the flexibility 
to vacation in a similar unit for a week any time of the year. If the purchaser owns a two-bedroom unit, he or she will vacation in any twobedroom unit within the resort during any time in the year over the contract life.

Biennial ownership: The vacation owner uses the unit or any unit of similar size for a week every other year, thus reducing the purchase price and the maintenance fees.

Banked usage: If the vacation owner has not used the unit, then the week accrues to the subsequent year and so the purchaser would have a twoweek vacation during the following year. Usually, this option is limited to three years.

Lock off or lockout: Timeshare floor plans come in a variety of sizes. A typical two-bedroom suite comprises of two adjoining self-contained units, each equipped with at least a bedroom, a kitchen and a living/ dining room area even though in most cases one bedroom is larger than the other. The suite can be separated by locking the door between the two bedrooms. If the vacation owner does not need the full use of the two bedrooms, one bedroom can be locked off for rent or exchange. The owner may choose to use the single bedroom for two weeks instead of two bedrooms for one week.

Fractional ownership/Private residence clubs: These types of timeshares tend to be 3-5 bedrooms designed to serve the high-income customers; they require more luxury amenities and services and involve longer time periods ranging from one to three months without necessarily being used consecutively. They give the owner the flexibility to use the property for an agreed-upon time any time during the year. The purchased time can also be traded for a stay at a different resort or for points. For example, a seven-day interval or a stay at the Grand Chateaux in Las Vegas can be traded for a time in a resort in Florida or South Africa or for points that can be exchanged for tailormade vacations in exotic places packed with options such as cruises and car rentals.

Destination Clubs/Points: This membership form allows the buyer to occupy a portfolio of upscale, luxury properties owned or operated by the Club Company or the network that the club may belong to, for a specified number of days or points.

\section{AUXILIARY PROGRAMMES}

Auxiliary programmes mainly exchange and secondary markets provide alternative sources of income for developers and are discussed here on that account.

Exchange programmes: These programmes are crucial to the industry. The owner of a timeshare trades the stay at a particular location for a stay at another equivalent resort in a different location or time or both, usually 
at some exotic place for a similar vacation period. The arrangement is facilitated by an exchange company functioning as a broker between the timeshare owners. Exchange firms charge membership fees for the service.

Timeshare developers tend to affiliate to major exchange companies such as the Resort Condominiums International (RCI) and Interval International (II), allowing timeshare owners to instantly become club members once the contracts become effective.

\section{Secondary market}

Under a deeded property arrangement, timeshare owners can resell their property by listing it with a resale agency and there are plenty of them on the internet ${ }^{6}$ or even on eBay. ${ }^{7}$ These agents usually require upfront fees to offset the cost of advertising the timeshare property. Many resorts have secondary market programmes that allow owners to sell their timeshare vacations. This arrangement is preferred by the resorts because they can control the price points at which timeshares are sold and hence maintain the high prices. The timeshare resort also charges fees for making this option available.

\section{TIMESHARE PROJECT STRUCTURE}

The development and construction process for a timeshare project typically goes through four main stages.

\section{Stage one: Feasibility studies}

Feasibility studies are carried out to determine the viability of the project. Potential costs and revenues associated with the project are developed including the amenities, floor plans, the way the property will be run (deeded property versus points/leasing and other variations), financing and the consumer mortgages needed for financing the purchases. All the costs incurred at this stage are expensed in the year in which they occur.

\section{Stage two: Development and construction}

Once the project is approved, the construction process, usually in a phased format, commences in tandem with the marketing campaign to sell the timeshare contracts. The costs incurred during this phase are capitalised and the revenues from the contract sales are recognised as a percentage of the per cent completion.

\section{Stage three: Completion}

Once the construction is completed and the certificate of occupancy is issued, the costs and revenues are fully recognised. The developers establish a management agreement to run the resort on behalf of the timeshare owners. Usually, a homeowners association (HOA) is formed to play the oversight role. Sometimes, the HOA may manage the resort itself or contract it with a specialist management company, which may be different from the hotel resort developers. 


\section{Stage four: Marketing and sales}

The marketing and promotion campaign for timeshare contracts begins immediately after breaking the ground for construction and past the completion date until all the contracts are sold. This lead time is necessary because of the high volume of contracts that have to be sold and the complexity of the timeshare product. Each unit in the resort potentially needs up to 52 contracts and for a 100-unit resort, the contracts amount to 5,200.

Timeshare ownership is different from the traditional real estate ownership in that timeshares represent an advance purchase of a vacation rather than an investment. Potential buyers are not looking to invest in timeshares; they have to be persuaded to do so. For this reason, advertising and promotion campaigns are aggressive. Potential customers are overtly accosted in the street, hotels, shopping malls or through direct mailing or on the internet and offered gifts ranging from free dinners and vacation packages to free hotel stays in exchange for attending timeshare sales presentations lasting up to 3 hours. Usually, these presentations are carried out on the development sites featuring models of the units being sold, accompanied by beautiful pictures of the resort locations. Consumers are pressured into signing the contracts right there and then.

In addition to being aggressive, advertising and promotion is expensive. Marketing costs are responsible for a significant portion of the final timeshare price accounting for at least 43 per cent ${ }^{8}$ and in most cases in excess of 50 per cent to the timeshare price. Compare this figure with Procter and Gamble, the global manufacturer of consumer products, whose worldwide television, print and electronic media costs amounted to 10 per cent ${ }^{9}$ of the sales.

Because the bulk of the costs are incurred through marketing rather than going towards the residence attributes such as art and spas, timeshares do not hold their values, thereby precluding these types of assets from being financed by banks because these assets cannot be held as collateral. For instance, a mortgage can be taken out on a house because the bank can sell the house to recover the money in the case where the customer defaults on the loan. This is not possible in the case of timeshares because the asset will be worth much less once put on the market. Consequently, there is very little consumer financing available to consumers even with an exceptional credit history. Consumer financing is therefore available through the developers at interest rates reminiscent of credit card interest rates because the risk associated with the timeshare property is considered on par with the unsecured credit.

With the above background, the methodology is provided below.

\section{METHODOLOGY}

To accomplish the stated objectives, the analysis focused on the Grand Chateaux hotel in Las Vegas currently selling timeshares. The resort is owned by the Marriott Vacation Club International, ${ }^{10}$ a division of Marriott International, Inc. The development and construction of the resort began in 2004 to replicate the grandeur of a French country side of the 1900s. The construction design called for 895 one-, two- and threebedroom suites with the floor plans varying from 820 to 2,095 square feet 
fitted with fully equipped kitchens, and separate living and dining areas, in four 37-storey towers arranged in an ' $x$ ' for easy access to the elevators and the rooms. ${ }^{11}$ Phase one, consisting of 126 villas, has been completed. The second phase, consisting of 200 units (Simpson and Stephen, 2002) with a budgeted $\$ 73 \mathrm{~m}$ capital outlay ${ }^{12}$ is in progress and is the focus of this analysis for two reasons. First, the marketing and promotion campaigns that include onsite presentations are in full blossom, allowing the most recent information to be captured. Secondly, the resort is a mixed-use facility allowing single-bedroom units to be used as the basis for the analysis because they are comparable in value to the hotel rooms.

The analysis uses the net present value (NPV) defined as the present value of the expected cash flows less the present value of any capital outlays over the life of the project. The NPV associated with a timeshare resort is as follows:

$$
\mathrm{NPV}=\mathrm{PVTS}+\mathrm{PVMF}+\mathrm{PVI}+\mathrm{PTS}-\mathrm{PDV}-\mathrm{POC}-\mathrm{E}
$$

where PVTS is the present value of the expected after-tax timeshare contract sales, PVMF is the present value of the future after-tax timeshare management fees, PVI is the present value of all the expected after-tax interest income paid to the developer by the timeshare owners who financed the units, PTS is the developer's tax savings from the interest payments on the timeshare resort mortgage, PDV is the present value of the amortised development and construction costs, POC is the present value of operating costs (POC) and $E$ is the initial cash equity.

The above equation is modified to suit the developer and consumer perspectives.

\section{Developer's perspective}

As the Grand Chateaux is a mixed-use facility (caters for timeshares as well as hotel guests) hotel resort, the developer can choose to devote the facility to timeshare ownership or operate it as an ordinary hotel by evaluating the economics of each alternative. The alternative with a higher NPV would be preferred. Since this is a comparative analysis, sunk costs (construction and development costs, and insurance) are ignored and only the unique costs and revenues associated with each alternative are considered. The following modified versions of the NPV were used for each alternative.

NPV Timeshare $=\mathrm{PVS}+\mathrm{PVF}+\mathrm{PVC}-\mathrm{PMC}$

where PVS is the present worth of the timeshare contract sales, PVF is the present worth of the future timeshare management fees, PVC is the present value of the net mortgage receipts paid by the timeshare buyers (amount paid by the mortgage buyers less the amount paid out by the developers to their creditors on the assumption that the money loaned out was borrowed) and PMC is the present value of the marketing costs.

In the case of the hotel operation, the equation becomes 
where PRC is the revenue from the hotel charges. The revenue is the product of the number of rooms available, the average charge per room and the occupancy rate.

\section{Consumer perspective}

The cost equations for the three alternatives (a) taking future vacations, purchasing a timeshare unit with equity and mortgaging the timeshare unit, cost equations (summation of costs or the worth of costs (WC)) are as follows: ${ }^{13}$

$\mathrm{WC}$ of vacation $=\mathrm{PR}+(1+\mathrm{INF}) \mathrm{PR}+$ Taxes

where $\mathrm{PR}$ is the room charge, INF is the cost escalation rate (inflation rate) and ( $1+$ INF)PR denotes the sum of the escalated room prices and taxes (Taxes) paid on the room charges over the period under consideration.

The sum of costs for the equity purchase is:

WC of equity purchase $=\mathrm{P}+\mathrm{PMF}$

where $P$ is the purchase price of the timeshare unit and PMF is the sum of membership fees paid to the homeownership association for maintaining the timeshares and reserves for replacing furniture and appliances and club membership fees to be able to exchange the timeshare units with other weeks at different locations

$\mathrm{WC}$ of financed timeshare $=\mathrm{PIP}+\mathrm{PDP}+\mathrm{PPP}+\mathrm{PMF}+\mathrm{CC}$

where PIP is the sum of interest payment on the loan, PDP is the sum of the down payment on the timeshare, PPP is the sum of the principal repayment and $\mathrm{CC}$ is the closing costs. The closing costs are seen as negligible in the face of the other costs and therefore not included in the calculation, and the equation becomes

$\mathrm{PWC}$ of financed timeshare $=\mathrm{PIP}+\mathrm{PDP}+\mathrm{PPP}+\mathrm{PMF}+\mathrm{CC}$

\section{DATA}

The analyses used the following data extracted from the presentations by Marriott Vacation Club International Inc; a sales presentation on 13 May 2007 at the Grand Chateaux Hotel, another presentation called 'Vacation Ownership the Marriott Way' on 8 March 2007 and Marriott Annual Reports (2000-2006).

Room Charge:

Room Tax:

Price of single-bedroom suites: Interest on the vacation mortgage: Amortisation period:
$\$ 400$ per night escalated at

5 per cent for later years

15 per cent

$\$ 18,000$ per unit

14.99 per cent

10 years 
Down payment:

Marketing costs as percentage of Price:
10 per cent

43 per cent

The costs and revenues for the second phase and all the marketing expenses (43 per cent of the contract price) were 100 per cent recognised because selling timeshare contracts commences $12-18$ months prior to occupancy $^{8}$ and since phase one started in 2005 and each of the four phases was scheduled to be completed in 14 months (Simpson and Stephen, 2002) there was ample time to sell almost all the contracts.

\section{RESULTS}

\section{Developer's perspective}

The timeshare investment alternative yielded $\$ 292 \mathrm{~m}$ in benefits against the $\$ 264 \mathrm{~m}$ for hotels (as depicted in Tables 1 and 2), making the timeshare resort a better investment than the hotel operation and therefore preferred by developers. The higher benefits from the timeshare vacation option can be attributed to the multiple sources of income as discussed earlier and depicted in Figure 1 even though not all the income streams were included in the calculation. The benefits from the hotel operations

Table I: Timeshare operation

\begin{tabular}{|c|c|c|c|c|c|c|c|c|c|c|}
\hline Period ending & $\begin{array}{l}2007 \\
\$ m\end{array}$ & $\begin{array}{l}2008 \\
\$ m\end{array}$ & $\begin{array}{l}2009 \\
\$ m\end{array}$ & $\begin{array}{l}2010 \\
\$ \mathrm{~m}\end{array}$ & $\begin{array}{l}201 \mathrm{I} \\
\$ \mathrm{~m}\end{array}$ & $\begin{array}{l}2012 \\
\$ \mathrm{~m}\end{array}$ & $\begin{array}{l}2013 \\
\$ \mathrm{~m}\end{array}$ & $\begin{array}{l}2014 \\
\$ \mathrm{~m}\end{array}$ & $\begin{array}{l}2015 \\
\$ \mathrm{~m}\end{array}$ & $\begin{array}{l}2016 \\
\$ \mathrm{~m}\end{array}$ \\
\hline Contract sales & $180.00 *$ & 0.00 & 0.00 & 0.00 & 0.00 & 0.00 & 0.00 & 0.00 & 0.00 & 0.00 \\
\hline Interest receipts & $14.14 * *$ & 13.16 & 12.08 & 10.91 & 9.63 & 8.22 & 6.69 & 5.00 & 3.17 & 1.17 \\
\hline Down payment & $18.00^{\dagger}$ & 0.00 & 0.00 & 0.00 & 0.00 & 0.00 & 0.00 & 0.00 & 0.00 & 0.00 \\
\hline Club membership fees & $5 \quad 4.20$ & 4.20 & 4.20 & 4.20 & 4.20 & 4.20 & 4.20 & 4.20 & 4.20 & 4.20 \\
\hline Management fees & $8.33^{\ddagger}$ & 8.33 & 8.33 & 8.33 & 8.33 & 8.33 & 8.33 & 8.33 & 8.33 & 8.33 \\
\hline Marketing costs & 77.40 & 0.00 & 0.00 & 0.00 & 0.00 & 0.00 & 0.00 & 0.00 & 0.00 & 0.00 \\
\hline Net cash flow & 162.75 & 25.69 & 20.41 & 19.24 & 17.96 & 16.55 & 15.02 & 13.33 & 11.50 & 9.50 \\
\hline Benefits worth & 292.27 & & & & & & & & & \\
\hline
\end{tabular}

*Number of rooms $(200) \times$ number of weeks $(50$ weeks with two weeks reserved for maintenance $) \times$ the contract price $(\$ 18,000$ obtained from the Marriott Vocational International Inc's Presentation, 13 May 2007)

**The interest rate charged to timeshare owners is 13.99 per cent and it is assumed that this money has an opportunity cost of 5 per cent (Marriott Annual reports) resulting in the net interest receipt of 8.99 per cent

This amounts to 10 per cent of the contract price as required by the Marriott Vacation International Inc

¥ This is the prevailing amount being collected for the Grand Chateaux timeshare vacation ownership. From Marriott Vacations International Inc, I3 May 2007

Table 2: Hotel operation

\begin{tabular}{|c|c|c|c|c|c|c|c|c|c|c|}
\hline Period ending & $\begin{array}{l}2007 \\
\$ m\end{array}$ & $\begin{array}{l}2008 \\
\$ m\end{array}$ & $\begin{array}{l}2009 \\
\$ m\end{array}$ & $\begin{array}{l}2010 \\
\$ \mathrm{~m}\end{array}$ & $\begin{array}{l}201 \mathrm{I} \\
\$ \mathrm{~m}\end{array}$ & $\begin{array}{l}2012 \\
\$ \mathrm{~m}\end{array}$ & $\begin{array}{l}2013 \\
\$ m\end{array}$ & $\begin{array}{l}2014 \\
\$ m\end{array}$ & $\begin{array}{l}2015 \\
\$ m\end{array}$ & $\begin{array}{l}2016 \\
\$ m\end{array}$ \\
\hline $\begin{array}{l}\text { Room revenues* } \\
\text { Benefits worth }\end{array}$ & $\begin{array}{r}21.00 \\
264.14\end{array}$ & 22.05 & 23.15 & 24.31 & 25.53 & 26.80 & 28.14 & 29.55 & 31.03 & 32.58 \\
\hline
\end{tabular}

* Room revenues calculated as the number of rooms $(200) \times$ room rate $(\$ 400) \times$ number of days in a week $(7) \times$ Number of weeks sold $(50$, with two weeks reserved for maintenance purposes) $\times$ occupancy rates ( 75 per cent - the number of rooms rented out of the available rooms). The room costs were escalated at an inflation rate of 5 per cent per annum. The Marriott Presentation of 8 March 2007 (Vacation Ownership,The MarriottWay) attributes 43 per cent of the total sales of the timeshare project to Marketing and Sales costs while the balance is split between Product costs (40 per cent) and Development margin (I7 per cent) 


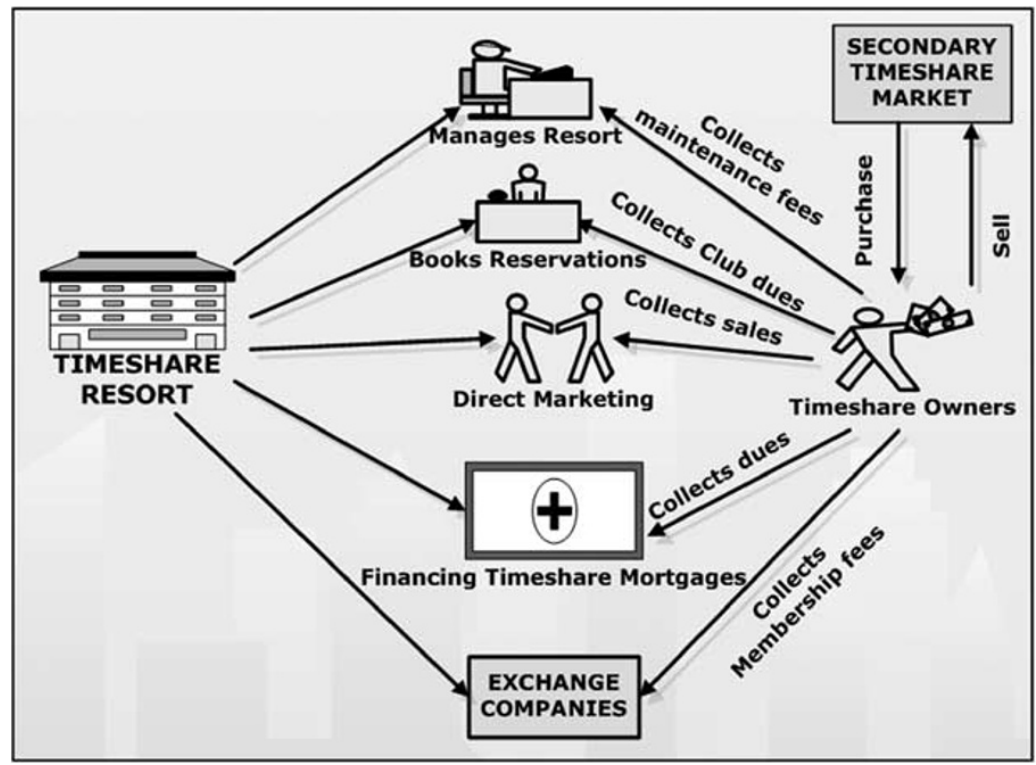

Figure I: Source of timeshare revenues

are in reality lower than portrayed here because the charge of $\$ 400$ per night used in the calculation is highly exaggerated as a quick search on the internet yielded $\$ 250$ per room per night ${ }^{14}$ as the charge for the Grand Chateaux hotel.

The profitability of the timeshare operations is supported by the data in the Grand Chateaux construction plan. Upon completion of the four wings at a cost of $\$ 240 \mathrm{~m}$, the resort is expected to house 850 units, generating about $\$ 800 \mathrm{~m}$ (Simpson and Stephen, 2002) from the contract sales, yielding a gross profit of $\$ 560 \mathrm{~m}$. The resort does not need to worry about operating costs since the timeshare owners will foot this cost. Instead, the resort will charge management fees to the owners for running the resort.

In addition to better economics, timeshare investments have a major advantage over hotel operations because of their ability to withstand economic fluctuations. The hotel lodging industry is extremely susceptible to variations in economic performance because business transient customers and leisure travellers severely curtail their travel during periods of economic downturns. In 2000, for example when the economy grew at 3.7 per cent (based on chained 2,000 dollars), the lodging industry generated a record $\$ 22.5 \mathrm{bn}$ in profits. In 2002 , following the dismal 1.6 per cent economic growth, the aftermath of the 2001 terrorist acts, profits plummeted to $\$ 14.2 \mathrm{bn}$.

In contrast, the timeshares segment of the lodging industry was not affected. In fact, this segment helped some hotel chains maintain profitability. For instance, in 2000, Marriott International Inc, one of the major players in the hospitality industry, gained $\$ 935 \mathrm{~m}$ in operating profits, with 15 per cent of that amount derived from timeshare intervals. In 2002, the operating profits declined by 24 per cent to $\$ 707 \mathrm{~m}$. During the same period, however, timeshare operating profits increased by 31 per cent from $\$ 140 \mathrm{~m}$ to $\$ 183 \mathrm{~m}$, and the timeshare contribution to the total operating profits for that year increased to 26 per cent. The 
Table 3: Marriott vacation club portfolio

\begin{tabular}{|c|c|c|c|}
\hline & $\begin{array}{l}\text { Percent of } 2006 \\
\text { contract sales }\end{array}$ & Average price & $\begin{array}{l}\text { Typical customer } \\
\text { household income }\end{array}$ \\
\hline \multicolumn{4}{|l|}{ Timeshares } \\
\hline Marriott vacation club & 73 & 27,000/week & $\$ 75,000-\$ 200,000$ \\
\hline $\begin{array}{l}\text { Horizons by Marriott vacation } \\
\text { club }\end{array}$ & 2 & $\$ 17,000 /$ week & $\begin{array}{l}\$ 40,000-\$ 99,000 \text { Value } \\
\text { Conscious }\end{array}$ \\
\hline \multicolumn{4}{|l|}{ Fractional \& whole ownership } \\
\hline The Ritz Carlton Club & 23 & $\begin{array}{l}\$ 375,000 / 21-28 \text { days, } \\
\$ 1 \text { million to } \$ 16 \text { Million } \\
\text { without ownership }\end{array}$ & $\begin{array}{l}\$ 250,000+ \\
\$ 3 \text { Million + Net worth }\end{array}$ \\
\hline Grand Residences-Marriott & 2 & $\begin{array}{l}\$ 254,000 / \text { Fraction, } \\
\$ 700,000 \text { to } \$ 2.9 \text { million/ } \\
\text { Without ownership }\end{array}$ & $\begin{array}{l}\$ 120,000 \\
\$ 500,000+\text { Net worth }\end{array}$ \\
\hline
\end{tabular}

Source: Vacation Ownership, the Marriott Way, 8 March 2007 presentation

timeshares' immunity to economic changes is attributed to the contractual obligations that the owners are subject to. Since the owners have already purchased the units, it does not matter to the developers whether the unit is occupied or not; payments have to be made. A secondary factor is timeshare ownership resonates more with consumers with higher income levels. As illustrated in the Marriott International portfolio shown below (Table 3), about 96 per cent of the timeshares owners earn over $\$ 75,000$ per year. This group of consumers is buffered against recessions.

\section{Consumer perspectives}

The results of these three ownership alternatives are depicted in Tables 4-6. Mortgaging the timeshare purchase is the most expensive alternative.

The mortgage option yielded $\$ 45,000$ in costs over a ten-year period compared with $\$ 39,000$ under the hotel lodging and $\$ 31,000$ under equity ownership. The economic ranking suggested purchasing with equity, followed by hotel lodging and mortgaging the timeshare suite. The option chosen depends on the preference of the purchaser. For consumers who want to lock in the cost (maintenance costs may change) and would like to mingle with other vacationers, a timeshare ownership is appropriate. Whether the suite should be funded using equity or mortgage loans is a function of the financial circumstances of the consumer. Consumers who cannot afford to purchase outright will need to mortgage the suites.

It should be noted that buying a timeshare is buying a vacation in advance and purchasing a timeshare vacation as an investment property is a bad idea because the purchase price is inflated to absorb the marketing costs, which run in excess of 43 per cent of the price of the villa. Consequently, these properties depreciate significantly. A suite selling for $\$ 18,000$ may fetch even lower than $\$ 100$ on the secondary market. ${ }^{15}$

Despite these problems, most timeshare owners appear to be satisfied with their purchases. In 2002, the American Resort Development Association (ARDA, 2002) reported that a survey of the State of the U.S. 
Table 4: Purchasing a timeshare ownership using equity

\begin{tabular}{|c|c|c|c|c|c|c|c|c|c|c|}
\hline Period ending & $\begin{array}{l}2007 \\
\$\end{array}$ & $\begin{array}{l}2008 \\
\$\end{array}$ & $\begin{array}{l}2009 \\
\$\end{array}$ & $\begin{array}{l}2010 \\
\$\end{array}$ & $\begin{array}{l}2011 \\
\$\end{array}$ & $\begin{array}{l}2012 \\
\$\end{array}$ & $\begin{array}{l}2013 \\
\$\end{array}$ & $\begin{array}{l}2014 \\
\$\end{array}$ & $\begin{array}{l}2015 \\
\$\end{array}$ & $\begin{array}{l}2016 \\
\$\end{array}$ \\
\hline Contract price & $18,000 *$ & 0 & 0 & 0 & 0 & 0 & 0 & 0 & 0 & 0 \\
\hline Maintenance Fees & $833^{*}$ & 833 & 833 & 833 & 833 & 833 & 833 & 833 & 833 & 833 \\
\hline $\begin{array}{l}\text { Club membership } \\
\text { fees }\end{array}$ & $420 *$ & 420 & 420 & 420 & 420 & 420 & 420 & 420 & 420 & 420 \\
\hline Total cost & 19,253 & 1,253 & 1,253 & 1,253 & 1,253 & 1,253 & 1,253 & 1,253 & 1,253 & 1,253 \\
\hline Cumulative costs & $\$ 30,530.00$ & & & & & & & & & \\
\hline
\end{tabular}

* Marriott Vacations International Inc, Presentation, I 3 May 2007

Table 5: Vacation lodging costs

\begin{tabular}{|c|c|c|c|c|c|c|c|c|c|c|}
\hline Period ending & $\begin{array}{l}2007 \\
\$\end{array}$ & $\begin{array}{l}2008 \\
\$\end{array}$ & $\begin{array}{l}2009 \\
\$\end{array}$ & $\begin{array}{l}2010 \\
\$\end{array}$ & $\begin{array}{l}2011 \\
\$\end{array}$ & $\begin{array}{l}2012 \\
\$\end{array}$ & $\begin{array}{l}2013 \\
\$\end{array}$ & $\begin{array}{l}2014 \\
\$\end{array}$ & $\begin{array}{l}2015 \\
\$\end{array}$ & $\begin{array}{l}2016 \\
\$\end{array}$ \\
\hline Room rate per week* & 2,800 & 2,940 & 3,087 & 3,241 & 3,403 & 3,574 & 3,752 & 3,940 & 4,137 & 4,344 \\
\hline Plus room tax @10\%** & 280 & 294 & 309 & 324 & 340 & 357 & 375 & 394 & 414 & 434 \\
\hline Total cost & 3,080 & 3,234 & 3,396 & 3,565 & 3,744 & 3,931 & 4,127 & 4,334 & 4,551 & 4,778 \\
\hline Cumulative costs & $\$ 38,739.91$ & & & & & & & & & \\
\hline
\end{tabular}

* Based on $\$ 400$ per room per night over a seven-day period

**From Marriott Vacation International Inc.

Table 6: Purchasing a timeshare ownership using a mortgage contract

\begin{tabular}{|c|c|c|c|c|c|c|c|c|c|c|}
\hline Period ending & $\begin{array}{l}2007 \\
\$\end{array}$ & $\begin{array}{l}2008 \\
\$\end{array}$ & $\begin{array}{l}2009 \\
\$\end{array}$ & $\begin{array}{l}2010 \\
\$\end{array}$ & $\begin{array}{l}2011 \\
\$\end{array}$ & $\begin{array}{l}2012 \\
\$\end{array}$ & $\begin{array}{l}2013 \\
\$\end{array}$ & $\begin{array}{l}2014 \\
\$\end{array}$ & $\begin{array}{l}2015 \\
\$\end{array}$ & $\begin{array}{l}2016 \\
\$\end{array}$ \\
\hline Contract price & 18,000 & 0 & 0 & 0 & 0 & 0 & 0 & 0 & 0 & 0 \\
\hline Closing costs & $42 I^{*}$ & 0 & 0 & 0 & 0 & 0 & 0 & 0 & 0 & 0 \\
\hline Down payment & 1,800 & 0 & 0 & 0 & 0 & 0 & 0 & 0 & 0 & 0 \\
\hline Interest payment & 2,216 *** & 2,097 & 1,959 & 1,802 & 1,620 & 1,412 & 1,172 & 897 & 580 & 217 \\
\hline Principal & 801 ** & 920 & 1,058 & 1,216 & 1,397 & 1,605 & 1,845 & 2,120 & 2,433 & 2,800 \\
\hline Maintenance fees & 833 & 833 & 833 & 833 & 833 & 833 & 833 & 833 & 833 & 833 \\
\hline Club membership fees & 420 & 420 & 420 & 420 & 420 & 420 & 420 & 420 & 420 & 420 \\
\hline Total cost & 6,491 & 4,270 & 4,270 & 4,270 & 4,270 & 4,270 & 4,270 & 4,270 & 4,266 & 4,270 \\
\hline Cumulative costs & $\$ 44,918.96$ & & & & & & & & & \\
\hline
\end{tabular}

* Marriott Vacations International Inc.

***Amortised at 13.99 per cent

Timeshare Industry showed that almost 85 per cent of the owners were either 'somewhat' or 'very satisfied', which is remarkable. These numbers were almost identical to the results of a similar survey carried out in 1999. ${ }^{16}$

Sources of satisfaction included the services and activities available near the resorts (87 per cent), cleanliness and upkeep of the units (86 per cent), construction quality ( 85 per cent) and hospitality of the staff (84 per cent). ${ }^{17}$ 


\section{CONCLUSIONS}

This paper focused on addressing (a) why timeshares have proliferated over the past few years and (b) whether consumers should invest in timeshare vacation ownership. The secondary purpose was to ascertain whether consumers should buy timeshare vacations using equity or mortgage financing if the decision to enter into a timeshare contract is made.

Two divergent factors combined to drive the popularity of timeshares ownership among hotel owners. First, while the hotel operations earn revenues largely from hotel room charges, timeshare resorts have multiple sources, which include timeshare contract sales, interest payments on mortgaged suites, maintenance fees and club membership fees. Secondly, timeshares tend to be immune to variations in economic performance because the timeshare owners are contractually bound to occupy their units. The owners earn normally earn in excess of $\$ 75,000$ per year, allowing them to meet their obligations even during cyclical downturns. In contrast hotel operations are susceptible to economic performance because vacation travellers tend to severely curtail their travels during recessions, thereby depressing hotel operation revenues.

From the consumer perspective, timeshares are not suitable for investment property because the expensive marketing programmes inflate the prices. The high marketing expenses force the property value to depreciate considerably over a short period. Even with this problem, surveys suggest that the owners are generally satisfied.

Consumers should not enter into timeshare contracts, however, for investment purposes but for buying a vacation in advance. Even then, it is better to purchase outright instead of financing the purchase. The purchasing option chosen, however, depends on the owner's preference and financial circumstances.

\section{Notes}

1 Resort Timesharing in the United States. Presented by Ragatz Associates 2003, www. ragatzassociates.com.

2 The Management Consulting Partners, www.tmc-partners.com.

3 The American Resort Development Association, www.arda.org.

4 Resort Timesharing Industry, Resort Condominiums International, LLC, 2003 edition, www.rci.com.

5 This is the product of 100 units $\times 52$ weeks per year. In most cases, the resort would sell only 50 weeks, leaving the two weeks for maintenance purposes.

6 See for example www.lasvegas-timeshares.com, www.sellmytimesharenow.com, www. etimeshareresales.com/html/las_vegas_timeshare.html, www.timesharelifestyle.com.

7 www.ebay.com.

8 Vacation Ownership, the Marriott Way, 8 March 2007 presentation.

9 Procter and Gamble, 2006 Annual Report.

$10 \mathrm{http}: / /$ careers.marriottvacationclub.com/life_mvci.jsp, Accessed 15 May 2007.

11 Hotel-Online Special Report, Marriott Vacation Club International Opens First Las Vegas Resort, the Marriott Grand Chateau, 3 October 2005, http://www.hotel-online.com/News/ PR2005_4th/Oct05_GrandChateau.html, accessed 29 May 2007.

$12 \mathrm{http}: / /$ www.vegastodayandtomorrow.com/construction_stats.htm.

13 Note that no discounting is necessary since the comparison is carried out over the same period.

14 See www.expedia.com and www.hotels.com for instance.

15 Do a search for timeshare resale and you will have more than a thousand hits. Peruse any of those sites for the current timeshare contracts and you will be surprised at the disparity between the resale price and the contract prices. 
16 http://www.hospitalitynet.org/news/4013285.search?query=timeshare+satisfaction+rates.

17 Source: Economic Impact of the Timeshare Industry on the US Economy, 2006 edition, prepared by PricewaterhouseCoopers for AIF. The survey was conducted among timeshare owners who had an exchange membership. With a response rate of 13 per cent, the analysis included between 3,700 and 3,900 responses for each attribute.

\section{References}

ARDA (2002). A study of the timeshare and vacation ownership Industry, 2002, prepared for ARDA International Foundation by Price Waterhouse Coopers.

Crotts, J. \& Ragatz, R. (2002). Recent US timeshare purchasers: Who are they, what are they buying, and how can they be reached. International Journal of Hospitality Management. 21(3), 227-238.

Freitag, J.D. (2007), Vice President, US Lodging Industry Overview, Smith Travel Research.

Future Timeshare Buyers: 2003 Profile. Presented by Interval International, 2003.

Scott, B. (2007). Vacation Ownership's incredible streak continues with 15\% of Sales growth in 2006 Vacation Ownership World Magazine, February 2007, pp. 7-22.

Simpson, J. \& Stephen, C. Planning a \$240m 850 Unit Time-Share Project in Las Vegas, 15 February 2002, http://www.hotel-online.com/News/PR2002_1st/Feb02_Cloobeck.html, accessed 29 May 2007.

Sing, A. \& Horwitz, R. (2006). The Board of Directors in timeshare governance: Owner-managemen relations in timeshare resort operations. Journal of Retail and Leisure Property. 5(3), 185-196.

Sparks, B., Butcher, K. \& Pan, G. (2007). Understanding customer derived value in the timeshare industry. Cornell Hotel and Restaurant Administration Quarterly. 48(1), 8-48.

Wade, R. (1986). Rags, Inflation, changing buyer expectations, and timeshare valuation. The Appraisal Journal. 54(2), 246-256.

Woods, R.H. (2001). Important issues for a growing timeshare industry. Cornell Hotel and Restaurant Administration Quarterly. 42(1), 71-81.

Ziobrowski, A.J. \& Ziobrowski, B.J. (1997). Resort timeshares as an investment. Appraisal Journal. 65(4), 371-381. 